\title{
Does the $65 \mathrm{~cm}$ height cut-off as age proxy exclude children eligible for nutritional assessment in Bangladesh?
}

\author{
E. Ali, ${ }^{1}$ R. Zachariah, ${ }^{1}$ S. G. Hinderaker, ${ }^{2}$ S. Satyanarayana, ${ }^{3}$ W. Kizito, ${ }^{4}$ P. Alders, ${ }^{5}$ Z. Shams, ${ }^{6}$ \\ M. Allaouna, ${ }^{5}$ B. Draguez, ${ }^{5}$ P. Delchevalerie, ${ }^{5}$ D. A. Enarson ${ }^{7}$
}

http://dx.doi.org/10.5588/pha.12.0037

Setting: Kamrangirchar slum, Dhaka, Bangladesh.

Objective: During nutritional surveys and in circumstances when it is difficult to ascertain children's age, length/height cut-offs are used as proxy for age to sample children aged 6-59 months. In a context of prevalent stunting, using data from primary health care centres where age and height parameters were well-recorded, we assessed the proportion of children aged between 6 and 59 months who would be excluded from nutritional assessment using a height cut-off of $65 \mathrm{~cm}$ as a proxy for age $\geqslant 6$ months.

Design: This was a secondary data analysis of primary health centre data.

Results: A total of 2060 children were included in the analysis, with a median age of 24 months and a median height of $78 \mathrm{~cm}$ (SD 12.1, range 50-109 cm). There were $240(12 \%, 95 \% \mathrm{Cl} 10-13)$ children aged between 6 and 29 months, with a height $<65 \mathrm{~cm}$. The majority (59\%) of these children were females; $97.5 \%$ were aged 6 17 months.

Conclusion: In an urban slum setting in Bangladesh, the use of the current height cut-off as a proxy for age excludes vulnerable children from nutritional assessment and could also lead to underestimation of the prevalence of malnutrition in nutritional surveys.

B angladesh has one of the highest prevalence rates of stunting (low length/height for age) ${ }^{1}$ among children in the world. Approximately $43 \%$ of children aged $<5$ years are stunted ${ }^{2}$ and are at risk for acute malnutrition (wasting, low weight for length/height or nutritional oedema). ${ }^{1}$

Children living in slums are particularly vulnerable to malnutrition due to unhygienic conditions and economic hardship. Nutritional surveillance consisting of annual nutritional surveys and regular household screening is conducted in children aged between 6 and 59 months, who are the main target for guiding the need for and timing of interventions in these settings. ${ }^{3}$

In poor communities, where there is no tradition of recording the actual date of a child's birth and where the majority of child births happen at home, age documentation for children is often not available. ${ }^{4}$ This also occurs among migrant populations and in the context of natural disasters and conflicts. As a way of solving this practical problem, non-governmental organisations (NGOs) such as Médecins Sans Frontières (MSF) have resorted to using length/height cutoffs as proxy for age, and a standardised height mea- suring stick was developed with a lower height cut-off of $65 \mathrm{~cm}$ (a proxy for 6 months of age) and an upper cut-off of $110 \mathrm{~cm}$ (a proxy for 59 months of age; 5 Figure 1). These cut-offs were sourced from the 2006 World Health Organization (WHO) growth standards, which were derived from an international sample of healthy breastfed infants and children raised in an environment with minimal constraints to growth. ${ }^{6}$ The height cut-off value of $65 \mathrm{~cm}$ is equal to the $-1 Z$-score of a sex-combined height-for-age curve at 6 months of age. These height cut-offs are used to select children to be sampled for nutritional assessment in the absence of age data. Those children found to be malnourished are eligible for nutritional rehabilitation and support. ${ }^{7}$

In the complex context of Kamrangirchar slum in Bangladesh, age verification of children during household nutritional screening was a challenge. The majority of the parents were absent or seeking work, and the care givers were often family members or neighbours who didn't know the real age of the child. To solve this practical problem, height cut-off thresholds were used as a proxy for age.

As growth stunting is prevalent in Bangladesh, we hypothesised that a sizable proportion of children aged $\geqslant 6$ months would be unlikely to have attained a height of $65 \mathrm{~cm}$ and would thus be excluded from nutritional assessment. This is of particular concern, as these children are more vulnerable to malnutrition and related mortality risks. ${ }^{8}$

In Kamrangirchar slum, in Dhaka, Bangladesh, using data from primary health care centres, where age and height parameters were well recorded, we assessed the proportion of children aged between 6 and 59 months who would be excluded from sampling using the height cut-off of $65 \mathrm{~cm}$ as a proxy for age $\geqslant 6$ months.

\section{METHOD}

\section{Study setting and population}

This was a secondary data analysis of routine primary health care (PHC) data, and included all children aged 6-59 months who attended the clinics for the first time between July and September 2011 in the Kamrangirchar slum. Kamrangirchar has a population of 400000 living in an area of $3.1 \mathrm{~km}^{2}$. The population is mainly formed of migrants, and the majority of the mothers work. There are no governmental health services in the slum and PHC services are outsourced to NGOs. MSF PHC services are offered at two centres and focus on childhood malnutrition. There is no particular catchment area for both centres: they are
AFFILIATIONS

1 Médecins Sans Frontières, Medical Department (Operational Research), Brussels Operational Centre-Luxembourg, Luxembourg

2 Centre for International Health, University of Bergen, Bergen, Norway

3 International Union

Against Tuberculosis and Lung Disease, New Delhi, India

4 Médecins Sans Frontières, Keibera, Nairobi, Kenya

5 Médecins Sans Frontières, Operations Centre Brussels, Brussels, Belgium 6 Médecins Sans Frontières, Kamrangirchar, Dhaka, Bangladesh

7 International Union Against Tuberculosis and Lung Disease, Paris, France

CORRESPONDENCE Engy Ali

Médecins Sans Frontières Luxembourg

68 Rue de Gasperich L-1617, Luxembourg Tel: (+352) 332522 Fax: (+352) 335133 e-mail: engy.y.ali@ gmail.com

ACKNOWLEDGEMENTS This research was supported through an operational

research course jointly developed and run by the Centre for Operational Research, International Union Against Tuberculosis and Lung Disease, Paris, France, and the Operational Research Unit, Médecins Sans Frontières (MSF), Brussels-Luxembourg. Additional support for running the course was provided by the Centre for International Health, UniverInternational Health, Univer.
sity of Bergen, Norway. Funding for the course came from an anonymous donor and the Department for International Development, UK. The study implementation was funded by MSF-Operations Centre Brussels, Belgium. Conflict of interest: none declared.

\section{KEY WORDS}

operational research; height; age; nutrition survey; malnutrition

Received 11 July 2012 Accepted 27 September 2012 First published online 15 November 2012 


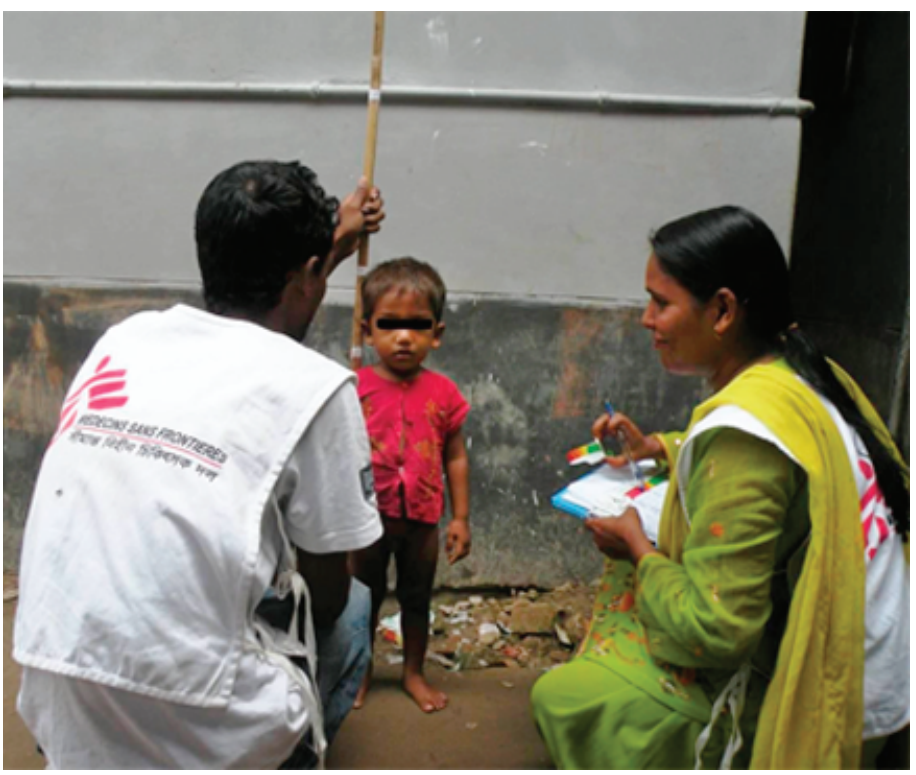

FIGURE 1 Using a height measuring stick to identify children between 65 and $110 \mathrm{~cm}$ of height in Kamrangirchar slum, Dhaka, Bangladesh.

located in the most condensed parts of the slum to cover the majority of the population.

All children presenting to the PHC for both preventive and curative care had their age, sex and anthropometric measurements recorded. Height/length was measured using a wooden stadiometer, with a precision of $0.1 \mathrm{~cm}$. Weight was measured using a hanging scale, with an accuracy of 100 g. Mid-upper arm circumference was measured with a tape measure. In each PHC centre there were two anthropometric measurers who had formal training in the measurement techniques. On-the-job supervision and refresher training were conducted at regular intervals to limit errors in measurement. Instruments used in MSF's health facilities around the world undergo formal validation, as was the case in Bangladesh.

Ages were verified using birth certificates, vaccination cards and local calendars of events. All services were free of charge and offered according to standard MSF and WHO guidelines. ${ }^{3}$

\section{Data and analysis}

Data obtained from the PHC register on height, age and sex were entered into EpiData version 3.1 (EpiData Association, Odense, Denmark) between November and December 2011. A sample size was calculated based on the hypothesis that $6 \%$ of the children attending the PHC aged $6-59$ months were $<65 \mathrm{~cm}$ in height. To detect the above with a 95\% confidence interval (CI) and 5\% error, the required sample size was calculated to be 2072 children.

We determined the proportion of children aged 6-59 months who had not attained a height cut-off of $65 \mathrm{~cm}$ (95\%CI and 5\% error). To assess the representativeness of the age distribution of the study sample, data on the age distribution of children included in the MSF annual nutritional survey in Kamrangirchar in $2011^{9}$ were compared with the study sample.

Data entry was validated by comparing randomly selected entered data with the register; the data were then cleaned of errors and aberrant records.

\section{Ethics approval}

The study was approved by the Ethics Advisory Group of the International Union Against Tuberculosis and Lung Disease, Paris,
TABLE 1 Age distributions of children included in the study (aged between 6 and 59 months) and those included in the 2011 MSF nutritional survey in Kamrangirchar, Dhaka, Bangladesh

\begin{tabular}{lccc}
\hline $\begin{array}{l}\text { Age } \\
\text { group, } \\
\text { months }\end{array}$ & $\begin{array}{c}\text { Study sample } \\
(n=2060)\end{array}$ & $\begin{array}{c}\text { Nutritional survey } \\
(n=832)\end{array}$ & \\
\hline $6-17$ & $\%(95 \% \mathrm{Cl})$ & $\%(95 \% \mathrm{Cl})$ & $P$ value \\
$18-29$ & $35(33.3-37.5)$ & $20(17.2-22.6)$ & 0.000 \\
$30-41$ & $24(22.1-25.8)$ & $26(22.8-28.8)$ & 0.26 \\
$42-53$ & $19(16.9-20.3)$ & $23(20.3-26.0)$ & 0.01 \\
$54-59$ & $16(14.6-17.8)$ & $23(20.2-25.9)$ & 0.000 \\
\hline
\end{tabular}

MSF = Médecins Sans Frontières; $\mathrm{Cl}=$ confidence interval.

TABLE 2 Characteristics of children aged $\geqslant 6$ months with a height of $<65 \mathrm{~cm}$ in Kamrangirchar, Dhaka, Bangladesh $(n=240)$

\begin{tabular}{lccrr}
\hline $\begin{array}{l}\text { Age group, } \\
\text { months }\end{array}$ & $\begin{array}{c}\text { Total } \\
n(\%)\end{array}$ & $\begin{array}{c}\text { Female } \\
n(\%)\end{array}$ & $\begin{array}{c}\text { Male } \\
n(\%)\end{array}$ & $\begin{array}{c}\text { Height } \\
\text { range, cm }\end{array}$ \\
\hline $6-17$ & $234(97.5)$ & $139(59)$ & $95(41)$ & $50-64.9$ \\
$18-29$ & $6(2.5)$ & $2(33)$ & $4(67)$ & $50.2-64.5$ \\
Total & $240(100)$ & $141(59)$ & $99(41)$ & - \\
\hline
\end{tabular}

France. The study met the Médecins Sans Frontières Ethics Review Board-approved criteria for analysis of routinely collected programme data.

\section{RESULTS}

Data on 2072 children were available in the electronic database Twelve children were excluded from the analysis: nine were missing records on height and three had aberrant records (two with height and one with age). Of the remaining 2060 children included in the analysis, 1042 (51\%) were males and the median age was 24 months. The median height was $78 \mathrm{~cm}$, with a standard deviation of 12.1 (range 50-109). On comparing the age distributions of the children included in the study sample with those included in the nutritional survey, which was based on a random cluster method, there was a significant difference between the age groups 6-17 and 42-53 months (Table 1).

Of the total sample, $240(12 \%, 95 \%$ CI $10-13)$ children aged between 6 and 29 months had a height $<65 \mathrm{~cm}$. Table 2 shows the age groups, sex and height ranges of these children. The majority of these children were females (59\%) and aged between 6 and 17 months (97.5\%; Figure 2).

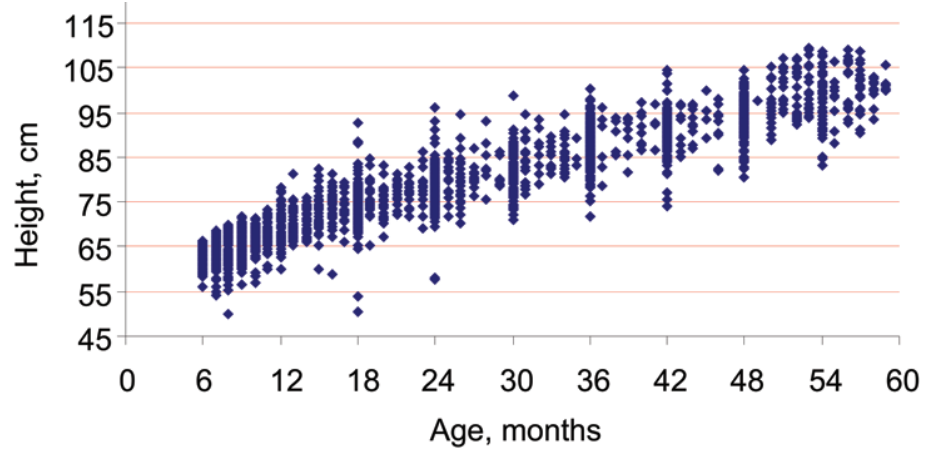

FIGURE 2 Height and age of the study population in Kamrangirchar slum, Dhaka, Bangladesh $(n=2060)$. 


\section{DISCUSSION}

The study confirms our hypothesis that, in a context of prevalent stunting, $12 \%$ of children aged 6-59 months are misclassified for age using the height cut-off of $65 \mathrm{~cm}$ as age proxy, and are thus excluded from nutritional assessments.

This study has several strengths: 1) this is the first study to assess the use of $65 \mathrm{~cm}$ height as a proxy for age $\geqslant 6$ months in an Asian context; 2) it was conducted in an urban slum context, which is unique; 3 ) rigorous attention was paid to verify children's age; and 4) the staff were well trained in anthropometric measurements.

An important limitation of the study is that there might be an issue of representativeness of the sample, as we used PHC data and access to the PHC and morbidity might have an influence on the sample. Notably, the majority $(97.5 \%)$ of the children who did not attain $65 \mathrm{~cm}$ in height were those aged 6-17 months. This age group constituted 35\% of the study sample in comparison with $20 \%$ of the community survey. This might be explained by the fact that younger children tend to be more vulnerable to morbidity episodes, and as such often constitute a higher proportion of children attending PHC centres.

On the other hand, repeated morbidity-which is more likely in the sample that presents to PHC centres-could influence retarded growth and thus increase the proportion of children in the age group 6-17 months, as seen in the PHC sample. This notwithstanding, the overall proportion of exclusion using the current height proxy of $65 \mathrm{~cm}$ is still too high.

Although the use of a locally developed calendar to verify children's age during a community survey instead of using height/ length as a proxy for age may be debatable, in contexts such as the Kamrangichar slum, age verification of children even using the local events calendar tends to be difficult due to parental absence. Finally, although our staff were trained in various methods for ascertaining age, the exact method of ascertainment of these parameters was not recorded in the register.

The findings of this study also highlight a number of concerns related to the use of height cut-offs to verify age in our setting. First, about one in ten children who should undergo nutritional assessment in infancy were excluded-the majority (97.5\%) of the exclusions occurred among children aged 6-17 months, who are the most vulnerable age group for malnutrition-related morbidity and mortality. ${ }^{10}$ This finding also implies that standardised WHO growth chart data, ${ }^{6}$ used as the basis for determining proxy heights for age, are inappropriate in such contexts of prevalent stunting. Second, the findings beg the following question: what should be the ideal height proxy for 6 months of age in our setting? This would require a community cluster survey and validity analysis to determine cut-offs with the highest positive predictive value. Our study was not designed to conduct such an analysis, and this will thus require further research. Due to height stunting, the upper height cut-off of $110 \mathrm{~cm}$ as a proxy for 59 months of age might also misclassify children aged $>59$ months as being below that age, as they might not have attained a height of $110 \mathrm{~cm}$. This will unnecessarily include children who are not in the target group for nutritional assessments. Here too, determining the ideal upper cut-off as an age proxy of 59 months will require further research.

Third, and most importantly, the use of height cut-offs as proxy for age is likely to introduce bias in nutritional surveys assessing malnutrition prevalence in the age group 6-59 months. This could have major public health implications, as nutritional interventions are guided by prevalence rates of malnutrition among such age groups. Fourth, our findings also highlight the need for national growth charts in a country such as Bangladesh, which has a high prevalence of stunting.

\section{CONCLUSION}

The use of the current height cut-off of $65 \mathrm{~cm}$ as proxy for age $\geqslant 6$ months in an urban slum setting in Bangladesh excludes vulnerable children, but steps are being taken to rectify this situation.

\section{References}

1 de Onis M, Onyango A, Borghi E, Siyam A, Blossner M, Lutter C. Worldwide implementation of the WHO Child Growth Standards. Public Health Nutr 2012; 12 April. [Epub ahead of print]

2 National Institute of Population Research and Training Bangladesh. Bangladesh Demographic and Health Survey 2007. Dhaka, Bangladesh: NIPORT, 2009

3 World Health Organization. Community-based management of severe acute malnutrition: a joint statement by the World Health Organization, the World Food Programme, the United Nations System Standing Committee on Nutrition and the United Nations Children's Fund. Geneva, Switzerland: WHO, 2007.

4 Food and Agriculture Organization of the United Nations. Guidelines for estimating the month and year of birth of young children. Rome, Italy: FAO, 2008

5 World Health Organization. WHO, UNICEF and SCN Informal Consultation on Community-Based Management of Severe Malnutrition in Children. SCN Nutrition Policy Paper No. 21. Geneva, Switzerland: WHO, 2005.

6 World Health Organization. WHO child growth standards: length/heightfor-age, weight-for-age, weight-for-length, weight-for-height and body mass index-for-age: methods and development. Geneva, Switzerland: WHO, 2006. http://www.who.int/childgrowth/standards/Technical_report.pdf Accessed October 2012.

7 World Health Organization. WHO child growth standards and the identification of severe acute malnutrition in infants and children: a joint statement by the World Health Organization and the United Nations Children's Fund. Geneva, Switzerland: WHO; 2009. http://www.who.int/nutrition/ publications/severemalnutrition/9789241598163_eng.pdf Accessed October 2012.

8 Pelletier D L, Low J W, Johnson F C, Msukwa L A. Child anthropometry and mortality in Malawi: testing for effect modification by age and length of follow-up and confounding by socioeconomic factors. J Nutr 1994; 124 (10 Suppl): 2082S-2105S.

9 Médecins Sans Frontières. Nutritional and retrospective mortality survey: Kamrangirchar, Bangladesh. Brussels Operational Centre-Luxembourg, Luxembourg: MSF, 2011.

10 de Onis M, Blössner M, Borghi E. Prevalence and trends of stunting among pre-school children, 1990-2020. Public Health Nutr 2011; 14 July. [Epub ahead of print]
Contexte:Quartier urbain pauvre de Kamrangirchar, Dhaka, Bangladesh.

Objectif : Au cours des enquêtes nutritionnelles et dans les circonstances où il est difficile de déterminer l'âge des enfants, des limites longueur-taille sont utilisées comme approches de substitution pour l'âge afin d'échantillonner les enfants âgés de 6 à 59 mois. Dans un contexte où l'arrêt de croissance était prévalent, nous avons évalué au moyen des données provenant des centres de soins de santé primaires, où les paramètres d'âge et de taille étaient bien enregistrés, la proportion d'enfants âgés de 6 à 59 mois qui seraient exclus de l'évaluation nutritionnelle en utilisant une taille limite de $65 \mathrm{~cm}$ comme approche substitutive pour un âge $\geqslant 6$ mois.

Schéma : Il s'agit d'une analyse secondaire des données des centres de santé publique primaires.

Résultats: Ont été inclus dans l'analyse 2060 enfants dont l'âge médian est de 24 mois et la taille médiane de 78 cm (DS 12,1; extrêmes 
50-109 cm). Nous avons trouvé 240 enfants (12\%; IC95\% 10-13) âgés de 6 à 29 mois et dont la taille était $<65 \mathrm{~cm}$. La majorité de ces enfants étaient de sexe féminin et 97,5\% étaient âgés de 6 à 17 mois. Conclusion: Dans un contexte urbain pauvre du Bangladesh, I'uti- lisation de la limite actuelle de la taille comme substitut pour l'âge exclut des enfants vulnérables de l'évaluation nutritionnelle et pourrait également sous-estimer la prévalence de la malnutrition dans les enquêtes nutritionnelles.
Marco de referencia: El barrio marginal de Kamrangirchar en Dhaka, Bangladesh.

Objetivo: En el marco de las encuestas nutricionales y en circunstancias cuando es difícil verificar la edad de los niños, se suelen utilizar los valores límite de la talla y la estatura como medida indirecta de la edad, cuando se practica el muestreo de los niños entre los 6 meses y los 59 meses de edad. En un entorno donde predomina el retraso de crecimiento, se usaron los datos de los centros de atención primaria de salud, donde se consignan adecuadamente los parámetros de la edad y la estatura, con el fin de evaluar la proporción de niños entre los 6 meses y los 59 meses de edad que quedarían excluidos de la evaluación nutricional al utilizar el valor límite de $65 \mathrm{~cm}$ como indicador indirecto de una edad de $\geqslant 6$ meses.
Método: Fue este un análisis secundario de los datos de un centro de atención primaria de salud.

Resultados: Se incluyeron en el análisis 2060 niños cuya mediana de la edad fue 24 meses y la mediana de la estatura fue $78 \mathrm{~cm}$ (desviación tipo: $12,1 \mathrm{~cm}$, intervalo de $50 \mathrm{~cm}$ a $109 \mathrm{~cm}$ ). Se encontraron 240 niños con edades entre 6 y 29 meses, cuya estatura era $<65 \mathrm{~cm}$ (12\%; IC95\% 10-13). La mayoría de estos niños (59\%) era de sexo femenino y en el $97,5 \%$ su edad oscilaba entre 6 y 17 meses.

Conclusión: En el ámbito de un barrio marginal en Bangladesh, el uso actual de los valores limite de la estatura como medida indirecta de la edad excluye de la evaluación nutricional a los niños vulnerables y podría además subestimar la prevalencia de desnutrición en las encuestas nacionales.
Public Health Action (PHA) The voice for operational research. Published by The Union (www.theunion.org), PHA provides a platform to fulfil its mission, 'Health solutions for the poor'. PHA publishes high-quality scientific research that provides new knowledge to improve the accessibility, equity, quality and efficiency of health systems and services.
e-ISSN 2220-8372

Editor-in-Chief: Donald A Enarson, MD, Canada

Contact: pha@theunion.org

PHA website: http://www.theunion.org/index.php/en/journals/pha Article submission: http://mc.manuscriptcentral.com/pha 